\title{
KONSEP DIRI REMAJA DALAM FILM INDONESIA: ANALISIS WACANA ATAS FILM REMAJA INDONESIA TAHUN 1970-2000-AN
}

\author{
Ratna Noviani \\ Sekolah Pascasarjana Universitas Gadjah Mada Yogyakarta \\ Email: ratna_noviani@yahoo.com
}

\begin{abstract}
Film is a system of representation, which provides information of social dynamics during the period, when the film is produced and distributed. This study is aimed to identify and reveal how teenage selfconcept is discursively constructed through film imagery and narrative in the context of Indonesian society. This study focuses particularly on the physical and psychological teenage self-concepts. The analytical Corpus is eight films for teenagers which were produced from the 1970s through the 2000s. Through the application of Norman Fairclough's critical discourse analysis, a detailed examination of these films reveals that there are similarities, modification and differences in the way in which teenage self-concept has been constructed from decade to decade. This study also identifies that teenage self-concept has been constructed through various discourses, among other things good versus bad teenagers, role model seeking, and of teenage lifestyle.
\end{abstract}

Keyword: Film, teenager, self-concept, discourse

\begin{abstract}
ABSTRAK
Film merupakan sistem representasi yang bisa menjadi jendela untuk melihat dinamika kehidupan masyarakat pada kurun waktu ketika film dibuat. Kajian dalam tulisan ini merupakan kajian tentang teks film yang bertujuan untuk mengidentifikasi, menganalisis, dan merumuskan bagaimana konsep diri remaja dalam konteks masyarakat Indonesia dikonstruksi dan diwacanakan melalui citra dan narasi film. Korpus kajian adalah delapan film remaja yang diproduksi dalam kurun waktu empat dekade yaitu dari tahun 1970-an hingga 2000-an. Konsep diri remaja yang dianalisis dalam kajian ini meliputi konsep diri fisik dan konsep diri psikologis. Dengan menggunakan model analisis wacana kritis dari Norman Fairclough, kajian mendalam terhadap kedelapan film tersebut menunjukkan adanya persamaan modifikasi dan juga perbedaan konstruksi konsep diri remaja dari dekade ke dekade khususnya melalui wacana remaja baik-baik versus remaja nakal, pencarian role model serta wacana tentang gaya hidup remaja.
\end{abstract}

Kata Kunci: Film, remaja, konsep diri, diskursus 


\section{PENGANTAR}

Film adalah salah satu media hiburan yang semakin populer dan diminati oleh khalayak umum. Lebih dari itu, film merupakan sebuah teks sosial yang merekam dan sekaligus berbicara tentang dinamika kehidupan masyarakat pada saat film tersebut diproduksi. Bisa dikatakan bahwa citra dan naratif dari sebuah film adalah jendela yang cukup signifikan untuk melihat dan memahami realitas sosial yang terjadi pada ruang dan kurun waktu tertentu. Film bertema remaja misalnya, merupakan entry point yang penting untuk menyimak liku-liku kehidupan para remaja. Berkaitan dengan hal ini, Ashadi Siregar (2008) menegaskan bahwa setiap media massa yang secara spesifik ditujukan pada khalayak remaja pada dasarnya adalah indikator dari pemikiran, nilai dan juga cara pandang para remaja dalam masyarakat di mana media tersebut diproduksi dan didistribusikan.

Di dalam dunia perfilman Indonesia, film dengan genre remaja menjadi populer dan mulai ikut memainkan peran yang krusial sejak pertengahan 1970-an (Sen \& Hill, 2000: 153). Pada saat itu, remaja menjadi pasar yang sangat menjanjikan seiring dengan meningkatnya kesejahteraan dari kelas atas dan kelas menengah Indonesia. Sejak pertengahan tahun 1970-an mulai banyak diproduksi film remaja yang diadopsi dari novel-novel remaja yang sukses. Film-film remaja, seperti 'Ali Topan Anak Jalanan', atau 'Gita Cinta dari SMA' cukup fenomenal dan menjadi legenda. Bintang-bintang perempuan baru mulai muncul dengan memainkan peran protagonis sebagai anak SMA perkotaan, sebut saja Yessy Gusman atau Yati Octavia. Tren film remaja ini diikuti oleh produksi film remaja di tahun 1980-an yang ditandai dengan suksesnya film 'Lupus', yang merupakan adopsi dari novel laris- dan 'Catatan Si Boy', yang juga adopsi dari serial sandiwara radio yang sukses besar hingga dibuat sekuel-sekuelnya dan mampu bertahan hingga awal era 1990-an dan berhasil mengangkat pemain utamanya, yaitu Ryan Hidayat dan Onky Alexander yang notabene adalah pemain film baru menjadi menjadi idola baru anak muda pada waktu itu. Memasuki pertengahan tahun 1990-an, film Indonesia mengalami mati suri, yang ditandai dengan menurunnya jumlah produksi. Akibatnya, film remaja pada masa itu juga tak banyak lagi diproduksi. Setelah mengalami kelesuan produksi, seiring dengan krisis yang melanda dunia perfilman Indonesia pada dekade 1990-an, film bertema remaja kembali menjadi ujung tombak di awal dekade 2000-an.

Pasar remaja sebetulnya adalah pasar yang terus dibidik oleh para pembuat film di Indonesia. Film-film remaja tersebut tidak hanya menyajikan hiburan dan gambaran tentang dunia remaja di Indonesia, tetapi sebagai film yang secara spesifik bicara tentang remaja, mereka memuat asumsi-asumsi ideologis tertentu terkait dengan realitas remaja. Film remaja yang bercerita tentang remaja dan dinamikanya telah mampu memberikan warna bagi dunia perfilman dan juga bagi kehidupan remaja di setiap dekade dalam sejarah perfilman di Indonesia. Namun demikian, perlu dicatat pula bahwa meskipun industri perfilman Indonesia cukup produktif menghasilkan film bertema remaja sejak dekade 1970-an, namun kajian komprehensif yang secara spesifik berbicara tentang film remaja Indonesia masih sangat minim jumlahnya. Oleh karena itu, kajian di dalam tulisan ini difokuskan pada bagaimana film remaja di Indonesia membuat wacana tentang realitas dunia remaja. Secara khusus, kajian ini membahas tentang konsep diri remaja yang dikonstruksi melalui bahasa verbal maupun visual yang digunakan oleh film-film remaja dari dekade 1970-an hingga 2000-an. Dari analisis terhadap film-film remaja tersebut diharapkan tidak hanya wacana tentang konsep diri remaja saja yang akan teridentifikasi tetapi juga pergeseran wacana tentang realitas remaja dari dekade ke dekade. Dari pengalaman dan pengetahuan penulis, hingga saat ini belum ada kajian akademik yang secara komprehensif menganalisis realitas remaja yang direpresentasikan di 
dalam film Indonesia dan pergeseran atau perubahannya dalam rentang waktu empat dekade yaitu dari 1970-an hingga 2000-an. Bagaimana cara film Indonesia menggambarkan dan mendefinisikan realitas dalam kurun waktu tersebut belum pernah diungkap dan dianalisis secara mendalam. Padahal penelitian-penelitian paling aktual tentang hubungan remaja dan media menunjukkan bahwa film adalah media paling populer dan diminati oleh kaum remaja di samping televisi (Roberts dalam Kirsh, 2006: 77).

Media massa, termasuk film, telah menggantikan peran orang tua sebagai sumber informasi tentang berbagai hal. Apalagi sebagai tahap kehidupan di mana individu sedang mencari identitas diri, masa remaja sering dianggap sebagai masa yang rawan, penuh gejolak dan problematika. Pada masa ini, individu sangat membutuhkan apa yang disebut sebagai role model dalam rangka pembentukan identitas diri. Dalam hal ini, media massa sering diposisikan sebagai sumber informasi akan gaya hidup, cara bergaul, gaya bicara, dan berpenampilan (Widyastuti, 2006). Tak heran jika media yang dikhususkan untuk pasar remaja cenderung laris manis dan mampu menarik perhatian para remaja. Selain itu, media massa juga cenderung menjadi rujukan bagi anak-anak dan remaja untuk memperoleh informasi tentang posisi-posisi sosial (Hurlock, 1999: 45).

Sementara, seperti telah disebutkan di atas, media massa yang diperuntukkan bagi kaum remaja cenderung mengartikulasikan cara pandang dominan tentang kehidupan remaja di dalam masyarakat dan budaya di mana media tersebut diproduksi dan didistribusikan. Dengan kata lain, teks media termasuk teks film tentang dunia remaja memiliki interrelasi dengan konteks sosial di mana film itu diproduksi. Melacak wacana tentang dunia remaja yang ditampilkan oleh film Indonesia dalam kurun empat dekade menjadi sangat penting mengingat dunia remaja selalu mengalami perubahan seiring dengan perkembangan zaman.
Kajian akademik tentang film Indonesia sebetulnya semakin berkembang seiring dengan produktivitas film Indonesia yang juga semakin meningkat. Namun demikian, kajian tentang film-film Indonesia yang mengusung tema remaja, sampai saat ini masih sangat sedikit jumlahnya. Salah satu dari sedikit kajian akademik tentang film remaja Indonesia adalah studi yang dilakukan oleh David Hanan (2008) dari Australia dengan judul Changing Social Formations in Indonesian and Thai Teen Movies. Dalam kajiannya, Hanan menganalisis film Catatan Si Boy yang diproduksi pada tahun 1991 dan film Ada Apa Dengan Cinta? yang diproduksi pada tahun 2001. Kedua film tersebut merepresentasikan dua era politik yang berbeda di Indonesia yaitu era Orde Baru dan Pasca Orde Baru.

Dalam kajiannya, Hanan menemukan bahwa kedua film remaja tersebut banyak mewacanakan tentang pelestarian tradisi budaya meskipun remaja-remaja itu juga mengikuti arus budaya global. Selain itu, persoalan kelas dan perilaku seksual juga menjadi bagian penting dari analisis Hanan. Kedua tema ini dikaitkan dengan persoalan konsumerisme yang berkembang dalam masyarakat Indonesia dan juga dikaitkan dengan konteks politik dari dua rezim politik yang berbeda di Indonesia. Kajian ini mempertegas asumsi bahwa teks film selalu memiliki inter-relasi dengan konteks sosial dalam periode waktu di mana film tersebut diproduksi. Sayangnya, Hanan kurang membahas pergeseran konstruksi identitas diri remaja dan konflik-konflik yang dialami remaja dari era Orde Baru ke Pasca Orde Baru. Marshall Clark (2004) dalam karyanya Men, Masculinities and Symbolic Violence in Recent Indonesian Cinema juga menganalisis teks film remaja Indonesia, yaitu film Kuldesak. Namun, dalam kajiannya Clark tidak memberikan perhatian pada fenomena dunia remaja di Indonesia, tetapi melihat pada bagaimana definisi laki-laki Indonesia kontemporer secara umum ditampilkan dalam film tersebut. Clark juga mengkaitkan isu tentang maskulinitas dengan seksualitas, di 
mana ia menyimpulkan bahwa film Indonesia cenderung menyajikan maskulinitas heteroseksual sebagai citra laki-laki dominan di Indonesia. Dari beberapa kajian akademis tentang film remaja Indonesia, terlihat bahwa kajian tentang konstruksi diskursif konsep diri remaja dan pergeserannya dalam film Indonesia belum banyak ditemukan.

\section{Film sebagai Sistem Representasi dan Konsep Diri Remaja}

Kajian film yang berkembang sejak tahun 1970-an memberikan tekanan pada bagaimana film memproduksi makna-makna melalui citra dan naratifnya. Selain itu, kajian film juga mencoba memposisikan film sebagai sebuah teks yang sarat dengan operasi ideologi (Grant, 2003: xvii). Dalam hal ini, teks film memuat kode-kode diskursif tertentu yang berfungsi untuk membangun makna-makna. Film, mengacu pada Stuart Hall (1997: 28), adalah sebuah sistem representasi di mana praktik-praktik pemaknaan dilakukan. Makna-makna diproduksi melalui bahasa dengan menggunakan kode-kode atau tanda-tanda yang mensimbolisasi atau merujuk pada objek, orang, peristiwa atau hal-hal yang dianggap sebagai "the real world". Film dalam konteks ini bekerja seperti bahasa yang memuat kode-kode atau tanda-tanda yang berfungsi untuk memproduksi makna-makna. Sebagai sebuah sistem representasi, film adalah entitas yang tidak diproduksi dalam keadaan vakum. Sebaliknya, film adalah sebuah teks sosial yang selalu memiliki interrelasi dengan konteks sosial budaya di mana teks tersebut diproduksi, didistribusikan, dan dikonsumsi (Kellner, 1995: 102).

Berkaitan dengan praktik atau operasi ideologis di dalam teks media, termasuk film, Stuart Hall (1995: 19) mengemukakan bahwa media [film] adalah situs yang cukup signifikan untuk produksi, reproduksi maupun transformasi ideologi. Apa yang diproduksi oleh media (film) dalam hal ini merupakan representasi realitas sosial yang merupakan jendela untuk memahami seperti apa reali- tas itu dan bagaimana ia bekerja. Film, oleh entry point yang penting untuk melihat dan memahami isu-isu atau perubahan-perubahan sosial yang terjadi di dalam masyarakat.

Film remaja adalah sebuah genre atau kategori dalam film yang menunjukkan bahwa film tersebut diformat secara spesifik dan ditujukan pada remaja. Icon Group (2008) mendefinisikan film remaja sebagai, "A film genre in which the plot is based upon interests targeted of teenagers" (sebuah genre film di mana plotnya mengacu pada kepentingankepentingan dari khalayak targetnya yaitu remaja). Sementara itu, Krishna Sen \& David T. Hill berpendapat bahwa film remaja umumnya tergantung pada konstruksi remaja secara visual, sosial maupun linguistik (2000, 153). Dengan kata lain, film remaja mencoba berbicara tentang remaja dengan bahasa remaja kepada para remaja.

Remaja sendiri sering didefinisikan sebagai masa transisi antara masa kanakkanak dan masa dewasa (Brown et al., 2000: 2). Dari sisi usia, para psikolog perkembangan menetapkan remaja sebagai individu yang berumur antara 8-17 tahun. Pada tahap ini, individu mengalami perubahanperubahan mulai dari fisik, kognitif, perkembangan sosial, maupun psikologis. Masa remaja juga dikenal sebagai masa di mana para remaja sedang berusaha mencari identitasnya (Widyastuti 2006). Upaya ini seringkali melibatkan penggunaan media massa, termasuk film. Penelitian menunjukkan, bahwa dalam sehari remaja menggunakan sepertiga waktunya untuk mengkonsumsi media. Penelitian yang dilakukan Roberts et al. (2005) yang dikutip oleh Kirsh (2006: 77) menunjukkan bahwa para remaja menghabiskan waktu hampir sembilan jam untuk mengkonsumsi media.

Dalam hal ini, film merupakan salah satu media yang populer dan paling diminati di kalangan remaja. Tidak mengherankan jika berkembangnya genre film remaja cenderung berkaitan dengan persoalan pasar. Secara umum, menurut Shary (2005: 1) film remaja telah menjadi media hiburan 
yang paling berpengaruh di dunia karena ia berperan besar dalam proses pembentukan gagasan-gagasan budaya yang berkaitan dengan sejarah, perilaku maupun nilai-nilai yang berkaitan dengan dunia remaja. Mengacu pada apa yang sudah diungkapkan sebelumnya, film remaja bisa menjadi jendela untuk melihat bagaimana realitas remaja dan pandangan serta sikap masyarakat terhadap kaum remaja.

Dalam konteks dunia perfilman Indonesia, Krishna Sen \& David T. Hill (2000: 153) juga menegaskan bahwa popularitas film remaja di Indonesia sangat erat kaitannya dengan munculnya pasar remaja yang merupakan akibat dari meningkatnya kesejahteraan kelas menengah dan kelas atas Indonesia. Fenomena ini terutama bisa ditemui pada dekade 1980-an, di mana produksi film remaja menunjukkan peningkatan yang cukup pesat. Pasar film remaja juga mengalami peningkatan lagi sejak awal 2000-an setelah berakhirnya krisis moneter yang melanda Indonesia dan khususnya dunia perfilman pada pertengahan 1990-an. Mulai awal 2000-an, semakin banyak film bertema remaja yang diproduksi dan diputar di Indonesia (Kompas, 2006). Dari segi isi cerita, film-film remaja Indonesia cenderung mendefinisikan masa remaja sebagai sebuah fase kehidupan yang sarat dengan perilaku menyimpang dan konflik-konflik (Sen \& Hill 2000: 153).

Problematika remaja seperti ini secara naratif dipecahkan ketika individu mulai beranjak dewasa. Dalam hal ini, individu dianggap sudah mulai melakukan penerimaan terhadap nilai-nilai sosial yang berlaku dalam masyarakat. Konflik-konflik antar-generasi umumnya tidak mendapatkan tempat dalam teks-teks film tersebut. Memasuki tahun 2000-an, tema cerita dari film remaja mulai mengalami perubahan, meskipun persoalan seputar percintaan, komunikasi antar-teman dan relasi dengan orang tua masih cukup mendominasi. Namun, setting film remaja pada periode ini tidak lagi melulu seputar anak sekolah dan gambaran remaja pun sudah jauh lebih luas dan kompleks.
Berkaitan dengan wacana identitas, film-film remaja juga cenderung memotret proses konstruksi konsep diri atau pencarian identitas diri oleh para remaja. Dalam hal ini, teks film bisa menjadi indikator untuk melihat proses-proses tersebut (Shary, 2005). Konsep diri sering didefinisikan sebagai "the image we hold of ourselves" (Hoge \& Renzully dalam Gross, Rinn \& Jamieson (2007: 242). Sementara, Corey \& Peterson (2003) mendefinisikan konsep diri secara lebih luas yaitu sebagai konsep yang dimiliki setiap individu tentang dirinya sendiri dan citra diri individu di mata orang lain. Konsep diri atau identitas diri, dalam hal ini, berhubungan dengan pertanyaan-pertanyaan tentang "siapa saya" dan bagaimana orang lain melihat "saya".

Menurut Elizabeth Hurlock (1979) konsep diri memiliki dua komponen utama yaitu physical self concept yang berkaitan dengan citra seseorang mengenai penampilan fisiknya dan pentingnya penampilan fisik itu untuk perilaku dan harga diri individu dan psychological self concept yang berkaitan dengan pikiran, perasaan atau emosi. Konsep diri psikologis ini terdiri dari kualitas dan kemampuan yang dimiliki individu seperti kemandirian, kepercayaan diri, pendirian yang teguh atau kebalikan dari sifat-sifat itu (Retnaningsih 1996, 35).

Seperti telah dikemukakan sebelumnya, bahwa konsep diri atau identitas diri ini selalu mengalami perubahan dan bersifat dinamis. Identitas diri tidak pernah final tetapi selau berada dalam proses. Berkaitan dengan hal ini, Michel Foucault, pemikir dari Perancis menyebutkan bahwa identitas itu tidak pernah stabil dan statis, karena identitas dibentuk atau diproduksi di dalam wacana. Wacana dalam bahasa Foucault adalah "a group of statements which provide a language for talking about, a way of representing knowledge about, a particular topic at a praticular historical moment" (Hall, 1997: 44). Wacana, menurut Foucault, adalah produk dari kuasa atau power. Ia bekerja membentuk dan mendefinisikan subjek maupun pengetahuan. Wacana juga sering dipahami sebagai sebuah rezim kuasa/pengetahuan 
(power/knowledge) yang merumuskan topiktopik yang dianggap penting, tidak penting, krusial, dan sebagainya. Foucault juga menegaskan bahwa wacana itu tidak pernah stabil dan statis, tetapi selalu berubah setiap saat dan oleh karenanya memiliki konteks sosial dan historis yang spesifik.

Korpus kajian adalah teks film Indonesia bertema remaja yang diproduksi dan didistribusikan pada tahun 1970-an hingga 2000-an. Ada delapan film bertema remaja yang diteliti sebagai representasi dari masing-masing dekade, mulai dari 1970-an hingga 2000-an. Film remaja yang dipilih untuk kajian ini adalah film dengan tema remaja yang khususnya berbicara tentang remaja berusia sekolah yaitu tingkat SMA. Setiap dekade dipilih dua film dengan alasan bahwa produksi film bertema remaja tidaklah banyak untuk tiap dekade, apalagi remaja tingkat SMA. Oleh karena itu, penulis hanya memilih dua film saja untuk setiap dekadenya. Pemilihan film untuk masing-masing dekade berdasarkan pada ketersediaan dokumentasi film serta popularitas film pada saat diluncurkan. Hal ini misalnya berdasarkan pada data jumlah penonton dan/atau penghargaan perfilman yang diterima oleh film-film tersebut.

Kedelapan film tersebut adalah Ali Topan Anak Jalanan (1977), Gita Cinta dari SMA (1979), Merpati Tak Pernah Ingkar Janji (1986), Lupus I: Kejarlah Daku Kau Kujitak (1987), Ricky Nakalnya Anak Muda (1990), Olga dan Sepatu Roda (1992), Ada Apa Dengan Cinta? (2001) dan Ekskul (2007). Kedelapan film tersebut dianalisis menggunakan metode analisis wacana kritis dari Norman Fairclough, untuk membongkar dan mengkaji bagaimana konsep diri remaja dikonstruksi secara diskursif di dalam teks film. Wacana dalam pandangan Fairclough (2000: 309) meliputi penggunaan bahasa baik dalam bentuk tulisan maupun verbal, serta citra visual dan juga bentukbentuk komunikasi non-verbal.

Ada tiga dimensi analisis yang dikemukakan oleh Fairclough yaitu, analisis teks, di mana teks diasumsikan sebagai rekaman peristiwa dan berfungsi mengkomunikasikan fakta tertentu. Dimensi yang kedua adalah praktik diskursif, yang berkaitan dengan proses-proses sosial yang terlibat dalam proses produksi maupun interpretasi teks. Dalam pengertian ini proses produksi dan interpretasi teks turut dipengaruhi oleh norma-norma, aturan, perilaku atau kesepakatan-kesepakatan tertentu dalam masyarakat. Proses-proses tersebut terekam dan termuat di dalam proses penggunaan bahasa. Dimensi yang ketiga adalah praktik sosial budaya, di mana teks dilihat sebagai bagian dari praktik sosial dan budaya tertentu. Interrelasi antara teks dengan aspek-aspek sosial budaya yang lebih luas akan diamati dan dikaji pada tahap ini.

\section{PEMBAHASAN}

Hal-hal yang berkaitan dengan cara individu melihat dirinya sendiri dan menunjukkan siapa dirinya kepada orang lain merupakan sesuatu yang dipelajari dan dihasilkan dari pengalaman. Artinya, konsep diri individu tidak melekat atau inheren pada individu sejak lahir. Konsep diri pada dasarnya merupakan refleksi dinamis dari dunia sosial di mana seorang individu hidup. Analisis tentang konsep diri remaja yang diwacanakan dalam delapan film remaja Indonesia dari dekade 1970-an hingga dekade 2000-an meliputi konsep diri fisik yaitu citra yang dimiliki dan ditampilkan individu tentang fisiknya serta kesan yang ditampilkannya pada orang lain dan konsep diri psikologis yaitu sifat-sifat dan karakteristik psikologis yang dimiliki dan ditampilkan individu pada orang lain. Kajian mendalam terhadap kedelapan film tersebut menunjukkan adanya persamaan, modifikasi dan juga perbedaan konsep diri remaja dari dekade ke dekade.

\section{Remaja Baik vs Remaja Nakal}

Wacana tentang remaja ideal atau remaja yang dianggap baik di dalam film remaja dari dekade ke dekade tidak menunjukkan adanya perubahan yang berarti. Bahkan bisa dikatakan bahwa film remaja In- 
donesia memiliki konstruksi yang cenderung sama tentang sosok remaja yang dianggap baik maupun remaja yang dianggap nakal. Sosok tentang remaja ideal dimunculkan lewat film-film remaja itu melalui wacana tentang tubuh baik tubuh luar (baca: penampilan) dan tubuh dalam (baca: kepribadian dan kualitas psikologis). Sosok remaja yang baik adalah remaja yang cantik atau ganteng secara fisik, pandai, berprestasi dan tidak suka bikin ulah atau masalah.

Dalam film tahun 1970-an, Gita Cinta dari SMA (GCdS), kategori remaja yang dianggap baik ditampilkan lewat sosok Galih dan Ratna. Keduanya digambarkan sebagai remaja yang sederhana, cenderung pendiam, tidak suka berkonflik, pandai, rajin beribadah, dan patuh pada orang tua. Ratna, terutama, ditampilkan sebagai individu yang sederhana, rendah hati, tidak sombong, dan tidak materialistis, meskipun ia sendiri berasal dari keluarga yang cukup berada karena jabatan ayahnya sebagai kepala dinas pertanian di Indramayu.

Pada zaman Orde Baru, orang yang menjadi pejabat pemerintah, apalagi menjadi kepala dinas, adalah orang yang posisinya dianggap cukup penting. Tidak hanya tinggi secara ekonomi, tetapi secara sosial pun posisi pejabat pemerintah selalu dianggap tinggi dan terhormat. Hal ini memang berkaitan dengan posisi pegawai negeri sipil di zaman Orde Baru yang merupakan salah satu pilar utama pendukung Golkar, partai politik pendukung Soeharto (Tanjung, 2007: 153). Pada masa Orde Baru, PNS memang terkenal tidak netral karena PNS terikat kebijakan monoloyalitas dengan mengarahkan suara mereka hanya pada partai Golkar. Akibatnya PNS pun kemudian identik dengan suara pemerintah, hal ini menyebabkan posisi PNS sendiri di kalangan masyarakat dianggap sebagai posisi yang kuat, mapan, dan harus dihormati.

Sifat-sifat positif Ratna ini sangat ditonjolkan di dalam film GCdS untuk menggarisbawahi sosoknya sebagai remaja baik-baik. Bersama Galih, Ratna sama-sama ditampilkan sebagai murid teladan. Selain cerdas otaknya, Galih juga digambarkan memiliki keterampilan lain yang positif seperti jago main basket dan terampil berkesenian, seperti bermain gitar, menciptakan lagu, dan membuat puisi. Secara fisik, Galih juga ditampilkan sebagai sosok yang cakep atau ganteng. Hanya saja, wacana tentang penampilan fisik Galih yang ganteng dan menarik, tidak diekspresikan secara verbal, khususnya oleh teman-teman perempuannya. Akan tetapi kekaguman akan sosok Galih sebagai remaja yang baik, lebih banyak diarahkan pada citra diri psikologisnya sebagai individu yang cerdas dan memiliki kemampuan lebih dibanding teman-temannya dalam hal olah raga maupun seni.

Sementara itu, wacana tentang penampilan fisik perempuan secara eksplisit terlontar misalnya ketika teman-teman sekelas Ratna mengomentari penampilan fisik Ratna sebagai murid yang baru pindah ke SMA itu. Perbincangan tentang penampilan fisik Ratna yang dianggap "cantik" diwacanakan secara verbal di antara murid-murid laki-laki. Hal itu bisa dilihat misalnya dari potongan dialog di bawah ini:

$\begin{array}{ll}\text { Galih } & \text { : Siapa (sambil berbisik) } \\ \text { Teman sebangku : Murid baru. Cantik ya. } & \\ \text { Galih } & : \text { Ehmm.... } \\ \text { Teman Basket } & \text { : Eh, Nana (nama panggilan } \\ & \text { Ratna) itu cantik ya } \\ \text { Galih } & : \text { Naksir? }\end{array}$

Dari dialog-dialog yang digunakan dalam film GCdS terlihat bahwa tubuh luar atau penampilan juga menjadi salah satu cara untuk mendefinisikan remaja yang dianggap baik dan ideal.

Di tahun 1980-an, konstruksi tentang remaja ideal masih cenderung sama. Seperti tokoh Lupus misalnya, ia digambarkan sebagai remaja yang cerdas dan berprestasi meskipun dari sisi penampilan ia dianggap melanggar aturan sekolah. Secara umum, Lupus ditampilkan sebagai remaja SMA yang jahil dan tidak takut melakukan sesuatu yang dianggap melanggar aturan. Salah satu contohnya adalah rambutnya yang dibiarkan gondrong. Rambut gondrong dianggap jelek dan tidak diijinkan oleh pihak sekolah. Namun, rambut gondrong itu menjadi "termaafkan" ketika pihak sekolah 
mengetahui aktivitas positif dan prestasi yang ditunjukkan oleh Lupus, seperti ketika ia berhadapan dengan Kepala Sekolah (KepSek):

KepSek: Hmmm, yak Lupus, ahhh ... Kamu yang sering menulis laporan ilmu pengetahuan dari sekolah-sekolah yang lain kan.

Lupus: Iya Pak.

KepSek: Rambutmu gondrong, tapi ini melanggar peraturan. Apa kau tadi tidak kena pemeriksaan?

Lupus : Itulah, Pak. Kalau rambut saya dipotong seperti anak-anak lain, yahh, Bapak sulit mengenali saya. ...... Gimana Pak, saya bisa keluar? Saya akan selalu mengangkat sekolah ini.

KepSek: Iya, selamat untuk Anda. Selamat berkarya. Mumpung masih muda. Ingat, rambut tidak ada dispensasi.

Berdasarkan dialog itu, penampilan rambut gondrong Lupus dan teman-temannya dianggap tidak baik oleh pihak sekolah. Untuk itu, rambut mereka harus dipaksa untuk dipotong di sekolah. Namun, karena Lupus memiliki prestasi sebagai wartawan yang mampu mengangkat nama sekolah ia akhirnya dibiarkan memelihara rambut gondrongnya itu. Ia melawan pendapat pihak sekolah tentang citra rambut gondrong melalui prestasinya sebagai wartawan.

Konstruksi yang sama terlihat juga dalam film remaja tahun 1990-an misalnya dalam film Olga dan Sepatu Roda. Olga sebagai representasi dari remaja yang baik juga digambarkan sebagai remaja yang mampu menjaga keseimbangan antara belajar dan hobi. Ia memang tidak digambarkan sebagai sosok yang sangat pintar dan menonjol kecerdasaannya di sekolah, tetapi ia juga bukan anak yang prestasinya jelek di sekolah. Seperti terlihat dalam dialog berikut ini:

Olga : Ada apa Mam?

Mami : What's wrong with you? Nilai kamu dulu lumayan dibanding papi kamu

Olga : Belum mujur kali Mam

Mami : Nonsense!
Dialog di atas terjadi ketika Mami menemukan hasil ujian Fisika Olga yang ternyata tidak bagus. Dengan kata "dulu", Mami membandingkan prestasi Olga sebelumnya yang dianggap "lumayan" dengan hasil ujian Fisika tersebut. Hal ini menunjukkan bahwa Olga bukan sosok remaja yang bodoh sebetulnya, meskipun juga tidak terlalu cemerlang. Namun, film ini ingin menonjolkan prestasi Olga yang lain di luar dunia sekolah, yaitu prestasi yang berkaitan dengan hobinya, yaitu bermain sepatu roda. Film ini menggambarkan bahwa sebagai remaja yang baik, Olga mampu menyeimbangkan antara kegiatan belajar di sekolah dan hobi. Ini ditegaskan oleh komentar Papinya ketika berdebat dengan Mami tentang hobi Olga. "Mam, hobinya kan nggak jelek. Nggak ganggu sekolah. Apalagi raportnya bagus". Raport yang bagus di sekolah itu diimbangi pula oleh Olga lewat prestasinya dalam hal hobi. Di kamarnya misalnya terlihat deretan tropi, piagam penghargaan, dan medali yang diperoleh Olga dari beberapa kompetisi sepatu roda yang telah diikutinya seperti terlihat pada ilustrasi Gambar 1.

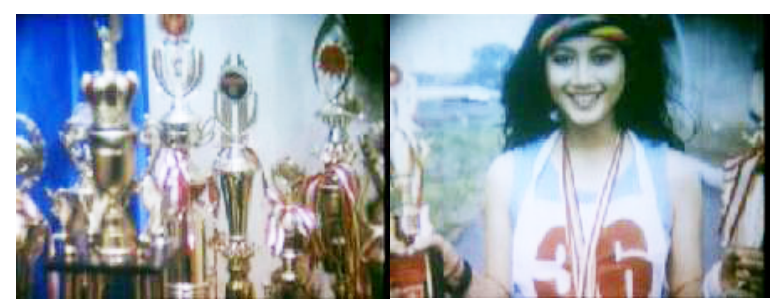

Gambar 1.

Olga dan trofi-trofi yang diraihnya

Di antara teman-teman bermainnya, prestasi Olga yang sering menang dalam kompetisi sepatu roda memang sudah sangat terkenal. Prestasi itu pula yang membuat teman-teman Olga menaruh respek padanya. Sosok remaja seperti ini juga direpresentasikan oleh sosok Cinta dalam film Ada Apa Dengan Cinta pada dekade 2000-an. Cinta digambarkan sebagai siswi SMA yang cantik, pintar, aktif, dan sangat populer di sekolahnya. Ia terkenal jago bikin puisi dan langganan juara lomba puisi tahunan yang diselenggarakan di sekolah. Ia juga suka menyanyi dan 
main gitar. Di sekolah, bersama keempat temannya ia aktif dalam kegiatan majalah dinding.

Mirip dengan gambaran remaja pada dekade 1990-an, remaja-remaja pada era 2000-an juga digambarkan sebagai remaja yang tidak melulu berurusan dengan sekolah. Mereka digambarkan sebagai remaja yang pandai dan berprestasi di sekolah tetapi tidak kehilangan waktu untuk santai dan bersenang-senang. Cinta dan teman-temannya misalnya digambarkan sebagai remaja yang kompak, yang tidak saja aktif dalam kegiatan-kegiatan ekstra-kurikuler di sekolah, tetapi mereka juga suka nongkrong atau nonton konser bersama.

Meskipun wacana tentang remaja ideal dan dianggap baik di film-film remaja itu cenderung sama dari dekade ke dekade, tetapi terlihat ada sedikit pergeseran terutama sejak dekade 1980-an. Berbeda dengan dekade sebelumnya, remaja pada film remaja sejak dekade 1980-an ditampilkan lebih aktif, enerjik, dan berani berdebat serta bernegosiasi termasuk dengan orang tua. Dalam film remaja produksi tahun 1980-an yaitu Lupus dan Merpati Tak Pernah Ingkar Janji, sosok remaja yang baik mulai digambarkan sebagai sosok yang berani memberontak dan menolak hal-hal yang dianggap tidak sesuai dengan pandangan hidupnya. Di film Lupus misalnya ditandai dengan kegigihan Lupus untuk menolak memotong rambut gondrongnya, meskipun rambut gondrong dianggap negatif.

Citra bahwa rambut gondrong itu negatif sebetulnya berkaitan dengan agenda rezim Orde Baru yang menganggap rambut gondrong adalah musuh. Pemerintah Orde Baru sejak tahun 1970-an, pernah mengeluarkan peraturan anti-rambut gondrong. Kebijakan tersebut yang dibarengi dengan hukum potong rambut di tempat bagi siapa pun yang melanggarnya. Di awal rezim Orde Baru, menjadi awal bagi negara untuk mempersiapkan kebijakan ekonomi dengan membuka investasi modal asing. Komunisme dihapuskan dengan menjaga stabilitas ekonomi. Di saat yang sama, dunia dilanda gerakan perlawanan budaya anakanak muda dalam bentuk hippies dan menjadi gerakan counter culture. Kehidupan hippies ditandai dengan trend fashion yang eksentrik, antara lain rambut gondrong.

Gerakan itu kemudian menyebar sampai ke Indonesia melalui media massa. Anakanak muda mulai berpakaian longgar, memanjangkan rambut, melakukan seks bebas, dan menggunakan narkotika. Mereka tumbuh menjadi generasi yang apolitis dan sibuk mencari identitas diri. Sementara itu di Indonesia, mahasiswa justru menjadi kelompok anak muda yang kritis terhadap pemerintah. Hal tersebut ternyata meresahkan pemerintah Orde Baru. Pemerintah mengkhawatirkan radikalisme mahasiswa yang menentang kebijakan pemerintah dan juga pengaruh gaya hidup hippies di kalangan anak-anak muda Indonesia. Untuk itulah kebijakan anti-rambut gondrong dikeluarkan. Kebijakan yang menjadi upaya melindungi anak-anak muda Indonesia sekaligus melakukan kontrol terhadap anak-anak muda lain yang kritis.

Pelarangan rambut gondrong dilakukan melalui dua hal, pertama, melalui kuasa wacana. Rambut gondrong dicitrakan negatif dalam berita yang muncul di media massa. Misalnya saja dalam judul-judul berita seperti "7 Pemuda Gondrong Merampok Bus Kota", "6 Pemuda Gondrong Perkosa 2 Wanita", dan "Disambar si Gondrong" menjadi sesuatu yang biasa (Yudhistira, 2010: 104). Kedua, pemerintah melakukan serangkaian tindakan fisik secara sistematis lewat peraturan yang ditindaklanjuti oleh institusi-institusi negara di daerah. Misalnya, anggota ABRI dan karyawan sipil yang bekerja di lingkungan militer beserta keluarganya dilarang berambut gondrong. Razia dan pelarangan rambut gondrong kemudian dilakukan di jalan-jalan. Salah satu implementasi dari kebijakan itu adalah kepala sekolah SMP dan SMA melakukan lokakarya dan menghasilkan keputusan untuk melarang siswa SMP dan SMA berambut gondrong. Hal inilah yang dilawan oleh Lupus dengan berani dan percaya diri. Ia tidak takut ber- 
hadapan dengan guru-guru untuk menolak memotong rambutnya.

Dalam dimensi yang berbeda, Guntur dalam film 'Merpati Tak Pernah Ingkar Janji' juga digambarkan jahil seperti Lupus dan berani melawan sesuatu yang dianggapnya tidak benar. Guntur berani mendekati Maria dan berusaha membebaskan Maria dari kekangan ayahnya. Lupus dan Guntur sama-sama melakukan perlawanan namun tidak dengan cara yang anarkis dan frontal. Remaja aktif dan percaya diri seperti Lupus dan Guntur adalah sosok remaja yang dianggap lazim pada dekade 1980-an. Sementara, remaja yang pendiam dan tidak percaya diri dianggap sebagai sosok remaja yang sudah ketinggalan jaman, seperti sosok Maria di dalam film Merpati Tak Pernah Ingkar Janji. Label "antik", "kuper", "norak" dan "udik" juga dilekatkan pada Maria karena sifatnya yang pendiam, pemalu, rendah diri, pasrah, dan sangat patuh pada ayahnya yang kolot.

Sedangkan remaja yang dianggap ideal di dalam film ini adalah remaja dengan sifat yang merupakan kebalikan dari sifat Maria. Teman-teman sekolah Maria digambarkan sebagai gadis-gadis yang ceria, ekspresif, dan memiliki kebebasan untuk menentukan pilihannya sendiri. Film ini menampilkan upaya negosiasi dan perlawanan yang dilakukan oleh kaum remaja dalam menentukan identitas dirinya. Remaja yang pendiam, pemalu, dan terlalu menuruti keinginan orang tua justru dianggap sebagai sosok remaja yang aneh, dan kurang pergaulan sehingga dianggap tidak "normal".

Ini agak berbeda dengan konsep diri remaja pada film tahun 1970 -an, di mana sosok remaja yang baik justru direpresentasikan melalui sosok yang pendiam, pemalu, dan patuh sekali pada orang tua seperti direpresentasikan oleh tokoh Ratna dalam film 'Gita Cinta' dan Anna Karenina dalam film 'Ali Topan'. Di dalam film 'Merpati Tak Pernah Ingkar Janji', remaja seperti itu justru menjadi bahan olok-olokan dan objek lelucon bagi teman-teman sebayanya. Berseberangan pendapat dengan orang tua oleh film ini tidak dianggap sebagai hal yang tabu dan bukan faktor yang membuat para remaja itu menjadi remaja yang dianggap tidak baik. Konstruksi seperti ini terus terlihat pada film-film remaja hingga dekade 2000-an.

Kedelapan film yang dianalisis dalam penelitian ini juga menunjukkan kecenderungan yang sama ketika berbicara tentang sosok remaja yang dianggap nakal. Kedelapan film tersebut menggambarkan remaja nakal sebagai remaja yang suka merokok, suka berkelahi, dan suka nongkrong bersama teman-temannya. Hal itu terlihat misalnya pada Gambar 2.

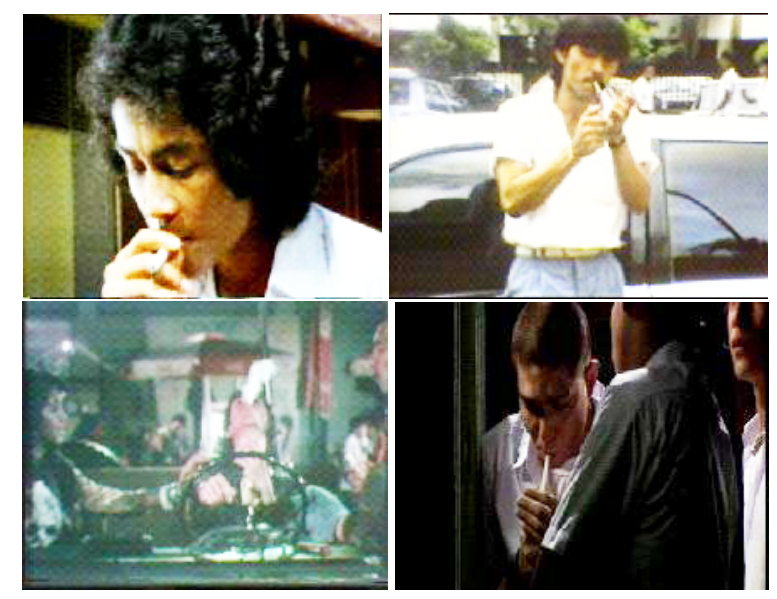

Gambar 2.

Searah jarum jam, sosok Ali Topan, Guntur, Ricky, dan Jerry adalah representasi remaja nakal. Merokok adalah salah satu aktivitas yang menunjukkan 'kenakalan" mereka

Remaja yang suka merokok seperti terlihat pada Gambar 2 dianggap sebagai remaja yang nakal. Meskipun remaja-remaja tersebut punya prestasi, namun karena kebiasaannya merokok, suka berkelahi dan nongkrong membuat prestasi itu menjadi seolah-olah hilang karena tertutup oleh hal yang dianggap nakal tadi. Dalam film 'Ali Topan Anak Jalanan' misalnya, Topan sebetulnya adalah murid yang cerdas, jago matematika, dan pintar main basket. Pada saat ujian, ia selalu bisa menyelesaikan soal dengan benar dan paling cepat di antara 
teman-temannya. Topan juga seorang remaja yang setia kawan dan suka menolong temannya. Akan tetapi sisi baik dari Topan tersebut menjadi tenggelam dengan perilaku bandelnya seperti yang tampak pada komentar gurunya pada dialog berikut ini, ketika Topan dipanggil menghadap direktur sekolah karena merokok di kantin:

\begin{tabular}{|c|c|}
\hline aya & Kenapa si To \\
\hline Bobby & Tahu, tuh \\
\hline Maya & $\begin{array}{l}\text { Oya, kenalkan Bob (sambil menun- } \\
\text { juk Anna di sampingnya) }\end{array}$ \\
\hline Bobby & Bobby \\
\hline Anna & Anna \\
\hline Guru & $\begin{array}{l}\text { Kawanmu itu (Topan) memang is- } \\
\text { timewa, pintar tapi bandel (sambil } \\
\text { geleng-geleng kepala) }\end{array}$ \\
\hline
\end{tabular}

Dari dialog di atas terlihat bahwa Guru pun melihat kualitas positif dari Topan yaitu pintar menjadi tereduksi atau bahkan bisa jadi hilang maknanya karena kualitas negatifnya sebagai remaja bandel. Hal yang sama juga terlihat pada sosok Ricky dalam film 'Ricky Nakalnya Anak Muda'. Prestasi Ricky dalam bidang softball pun juga membuat teman-temannya menaruh respek padanya, meskipun citra Ricky sebagai anak nakal masih tetap menonjol di dalam film itu. Ricky dikenal sebagai pemain softball yang hebat. Ia menjadi andalan teman-teman satu klub softball-nya. Beberapa dialog dari teman-teman Ricky menggambarkan kekaguman mereka atas kemampuan Ricky dalam bermain Softball.

$$
\begin{aligned}
\text { Lita } & \text { Wik, Ricky itu siapa sih? } \\
\text { Wiwik : } & \text { Nanti Lu juga bisa tau sendiri siapa } \\
& \text { dia. }
\end{aligned}
$$

Dari percakapan tersebut, teman-teman Ricky melihat dia sebagai sosok yang berprestasi bagi teman-teman seklubnya dan hal tersebut menjadi sisi positif seorang Ricky. Sementara di sisi lain, Wiwik menyebut Ricky seorang berandalan yang sok jagoan, mengacu pada perilaku Ricky yang suka berkelahi. Istilah berandalan mengacu pada seseorang yang memiliki perilaku menyimpang dalam masyarakat, sedangkan jagoan sendiri berarti adalah orang yang suka berkelahi. Lita bahkan mengajukan kemampuan Ricky bermain softball sebagai salah satu kriteria laki-laki yang bisa dibanggakan ketika sedang berdebat dengan ayahnya.

Ayah : Jadi kamu lebih suka sama cowok gondrong yang sok seniman itu ya? Anak pengusaha yang brengsek itu? Iya?

Lita : Dia baik, Pa.

Ayah : Lita, papa tau siapa ayahnya. Dan tau dari Bani siapa Ricky itu. Berandal pasar, tukang bikin onar, pemabuk, tukang ngebut. Apa yang kamu harapkan dari makhluk seperti itu? Ha? Apa?

Lita : Dia pemain softball terbaik, Pa.

Ayah : Sofball, sofball .. apa kamu bisa makan dengan itu?

Ayah Lita menilai Ricky sebagai sosok yang negatif. Hal itu ditunjukkan lewat serangkaian sebutan yang berkonotasi negatif. Misalnya rambut gondrong. Rambut gondrong memiliki konotasi negatif sebagai sosok pemberontak, yang anti tehadap kemapanan. Rambut gondrong identik dengan berandalan dan penjahat. Selain itu, ayah Lita juga menyebut Ricky dengan istilah "makhluk". Makhluk adalah sebutan bagi semua ciptaan Tuhan, misalnya makhluk hidup, makhluk sosial, makhluk beragama dan sebagainya. Namun, makhluk yang dimaksud ayah Lita di sini dapat dimaknai sebagai sosok di luar manusia. Kata makhluk yang diucapkan secara emosional, apalagi dengan beberapa istilah negatif sebelum kata tersebut diucapkan (berandal pasar, tukang bikin onar, pemabuk, tukang ngebut) menunjukkan bahwa makhluk yang dimaksud adalah bukan manusia, atau manusia dengan perilaku menyimpang.

\section{Role Model dan Gaya Hidup}

Masa remaja adalah masa ketika seorang individu sedang berusaha menemukan jati dirinya. Aktualisasi diri remaja dilakukan 
dalam rangka menegaskan jati diri tadi di mana dalam hal keluarga dan lingkungan, memegang peran yang sangat penting. Tidak jarang remaja berusaha mencari dan melakukan identifikasi dengan sosok-sosok di luar dirinya dan menjadikannya sebagai role model. Pencarian role model ini menjadi salah satu hal yang diwacanakan dalam film remaja yang menjadi korpus analisis. Ada kesamaan tentang role model yang menjadi rujukan para remaja dalam mencari jati dirinya. Dari dekade ke dekade terlihat bahwa idola dari negara Barat menjadi sosok yang disukai dan dianggap penting oleh remaja dan menjadi acuannya untuk melakukan identifikasi diri. Salah satu dialog dalam film GCdS menunjukkan hal itu:

\section{Antok : Erlin}

Erlin : Ada apa?

Antok : Bilang sama Nana, ada salam dari David Cassidy

Erlin : David Cassidy??..ha..ha..ha...

Antok : Ssstt....jangan keras-keras ngomongnya, ahh

Erlin : David Cassidy lagi nahan batuk? Boleh jadi.... (pergi sambil tertawa geli)

Antok : Huuhh (kesal)

Pada dialog di atas, terlihat bagaimana Antok mencoba mengidentifikasikan dirinya dengan figur David Cassidy, yaitu seorang aktor dan penyanyi asal Amerika. David Cassidy pada awal tahun 1970-an memang merupakan sosok artis terkenal terutama karena perannya dalam sebuah komedi situasi musikal berjudul The Patridge Family (www.davidcassidy.com). Meskipun demikian, popularitas David Cassidy di Indonesia lebih karena sosoknya sebagai musisi dengan lagu-lagunya.

Pada era tersebut, David Cassidy menjadi teen idol atau idola kawula muda yang sangat dipuja dan memiliki karier sukses di panggung hiburan. Antok mencoba mendefinisikan dirinya sebagai sosok yang mirip dengan David Cassidy. Upaya ini dia lakukan sebagai salah satu cara untuk mendekati Ratna. Meskipun upaya Antok ini mendapat cemoohan dari Erlin, tetapi film ini telah menunjukkan bahwa David Cassi- dy sebagai artis asing telah menjadi seorang role model bagi remaja di Indonesia, khususnya remaja pria seperti Antok. Biasanya, remaja tersebut akan melakukan peniruan atau imitasi, baik imitasi dari sisi fisiknya seperti mengikuti gaya rambutnya, cara berpakaian, gaya bicaranya maupun dari sisi non-fisik seperti sikap dan gaya hidupnya.

Mengenai bagaimana remaja Indonesia mengenal sosok David Cassidy tentu tidak bisa dilepaskan dari peran media, khususnya media radio, di mana lagu-lagu David Cassidy banyak diperdengarkan pada publik Indonesia. Identifikasi terhadap sosok dari Barat juga turut mempengaruhi selera berpakaian dari kaum remaja pada dekade 1970-an. Pada film 'Ali Topan' misalnya, Topan dan teman-temannya digambarkan mengenakan jaket yang ditempeli dengan beberapa badge. Model jaket seperti ini ternyata terinspirasi gaya berbusana anak-anak muda di Amerika pada tahun 1970-an khususnya ketika gerakan anti perang Vietnam digaungkan pada tahun 1972 (Herald, 2007: 9). Model jaket seperti itu terinspirasi oleh seragam militer dari tentara Amerika yang pada saat itu banyak dikirim ke Vietnam.

Selain itu, model celana jeans bell-bottoms seperti yang dikenakan oleh Topan dan teman-teman juga merupakan trend fashion yang sangat populer di Barat pada era 1960an dan 1970-an (Pendergast \& Pandergast. 2004: 902) sama halnya dengan sepatu kulit bersol tebal seperti yang dikenakan oleh Topan dan teman-temannya. Syal yang dililitkan di leher Topan juga merupakan trend fashion yang terinspirasi dari gaya penampilan penyanyi atau grup band rock terkenal pada era tersebut. Herald misalnya melihat bahwa penyanyi Rod Stewart atau David Bowie sering mengenakan syal semacam itu ketika bernyanyi di panggung (2007: 41).

Sementara dalam film Lupus, John Taylor, basis kelompok musik Duran-duran menjadi sosok ideal yang diidentifikasi oleh remaja-remaja seusia Lupus. Pada era 1980-an itu, John Taylor banyak disukai oleh remaja di seluruh dunia, termasuk Indonesia terutama perempuan karena wajahnya yang tampan. Penampilan Lupus, juga teman-te- 
mannya identik dengan gaya dan penampilan Taylor dengan rambut gondrong berjambul yang ditata klimis dengan menggunakan styling foam, dan $t$-shirt di bagian dalam plus kemeja yang terbuka di bagian luarnya yang dipadu dengan celana jeans. Begitu pula dengan penampilan remaja perempuan yang kerap menggunakan blus atau $t$-shirt dengan rok mini atau celana panjang yang berbahan jeans. Gaya berpakaian mereka adalah gaya berpakaian yang diadopsi dari fashion yang berkembang di Barat. Kedekatan anak muda secara kultural dengan para selebritis asing tersebut menjadi simbol gaya hidup anak muda yang modern.

Seperti telah dijelaskan di atas, anak muda adalah usia dinamis di mana mereka akan mudah terpengaruh gaya hidup asing. Dalam hal berpakaian, remaja menjadi agent of mode. Dalam hal ini, remaja yang modern adalah remaja dengan penampilan ala Barat. Oleh karena itu, mereka cenderung menghindari pergaulan atau menjadi bagian dari sesuatu yang dianggapnya tidak modern atau kuno dan ketinggalan zaman. Anak-anak muda menjadi tidak nyaman bergaul dengan mereka yang dianggap kuno. Trend fashion seperti itu bertahan sampai pada awal 1990-an, seperti yang terlihat dalam film Olga maupun Ricky. Pada film Ekskul, sosok yang menjadi idola remaja Joshua adalah Kurt Cobain. Pemujaan terhadap sosok Kurt Cobain di dalam film tersebut pada akhirnya membawa Joshua mengakhiri hidupnya dengan cara yang sama dengan yang dilakukan oleh Kurt Cobain yaitu menembak kepalanya sendiri dengan pistol.

Dari kedelapan film tersebut terlihat bahwa meniru gaya hidup yang berasal dari budaya asing dari dekade ke dekade dianggap sebagai sebuah keharusan jika remajaremaja itu tidak ingin disebut sebagai remaja kuno. Pada film 'GCdS dan Ali Topan', gaya hidup ala Barat ini memang diwacanakan sebagai sesuatu yang cenderung negatif dan dianggap bisa merusak rasa cinta pada budaya dan kesenian anak bangsa.
Pada film GCdS khususnya, remaja yang baik didefinisikan sebagai remaja yang tidak hanyut dengan pengaruh budaya asing. Menyatunya berbagai kesenian tradisional dalam satu panggung pentas seni dalam film tersebut merupakan metafora negara Indonesia, yang terdiri dari banyak etnis dan budaya, tetapi menjadi satu kesatuan, Bhinneka Tunggal Ika. Hal ini dipertegas misalnya melalui bahasa visual panggung. Para penari dan penyanyi dengan berbagai kostum tadi, tampil dengan sangat kompak di atas panggung dengan latar belakang bendera merah putih.

Wacana film ini tampaknya berkaitan dengan manuver pemerintahan Orde Baru pada era 1970-an untuk membangun Taman Mini Indonesia Indah. Proyek Taman Mini ini sebetulnya diprakarsai oleh Ibu Tien Soeharto, yaitu berupa miniatur pulau-pulau di Indonesia yang disatukan dalam satu taman. Meskipun memunculkan kontroversi seperti isu korupsi dalam proyek ini, namun pembangunan Taman Mini terus berlanjut sebagai upaya pemerintah Orde Baru untuk mempromosikan semboyan Bhinneka Tunggal Ika (Vickers 2005, 165). Tidak heran jika film Ali Topan yang juga diproduksi tahun 1970-an mewacanakan Topan dan teman-temannya sebagai sosok remaja yang negatif karena ditampilkan sangat mengikuti gaya hidup Barat baik dari fashion maupun selera lagu.

Namun, mulai tahun 1980-an film-film remaja justru semakin akrab dan terbiasa dengan simbol-simbol yang menandai pengaruh asing di Indonesia. Pada film tahun 1980-an, tidak hanya selera fashion yang meniru penyanyi dari Amerika, tetapi pesta dansa dan shopping mall sudah digambarkan sebagai bagian dari gaya hidup remaja pada saat itu. Maraknya gaya hidup yang dipengaruhi oleh budaya asing di dalam film remaja tahun 1980-an tampaknya berkaitan dengan konteks sosial di Indonesia pada dekade tersebut.

Pada pertengahan 1980-an, Indonesia mengalami booming ekonomi seiring dengan kebijakan liberalisasi ekonomi dan keterbu- 
kaan yang dicanangkan oleh pemerintah Orde Baru (Vickers, 2005: 198). Akibatnya Indonesia membuka pintu investasi untuk investor asing dan arus kapital pun bergerak dengan lebih bebas. Pada pertengahan 1980-an pertumbuhan ekonomi pun meningkat lebih dari $7 \%$, bisnis pun jadi booming di Indonesia. Hal ini bisa dilihat dari menjamurnya tanda-tanda budaya konsumen seperti shopping mall, café-café, dan restoran waralaba dari Barat seperti McDonald. Anak-anak muda di Indonesia pun mulai sangat akrab dengan budaya-budaya populer dari Barat dan mulai aktif berpartisipasi dalam gaya hidup konsumtif. Gaya hidup seperti ini makin terlihat jelas pada film remaja dekade 1990-an. Dalam film Olga dan Ricky, negara Barat yang mengacu pada Amerika dan Eropa terasa makin kental terutama terlihat dari dialog-dialognya yang banyak menggunakan sisipan-sisipan bahasa Inggris. Bahkan untuk bersekolah pun, 'luar negeri', terutama Barat dianggap sebagai tempat bersekolah yang ideal.

Kiblat ke Barat sebagai barometer kemajuan dan modernitas juga terkait dengan konteks sosial budaya di Indonesia pada tahun 1990-an. Seperti yang dikemukakan oleh Vickers $(2005,199)$ sejak dimulainya era keterbukaan pada pertengahan 1980-an, arus kapital dan budaya dari Barat seakan tidak terbendung lagi masuk ke Indonesia. Pada tahun 1990-an muncul istilah baru yang digaungkan oleh media yang menunjukkan keterlibatan Indonesia yang semakin intens dalam komunikasi dan interaksi global, yaitu globalisasi. Di era globalisasi ini, berbagai sekat yang membatasi hubungan antar bangsa pun menjadi semakin hilang berkat perkembangan media dan teknologi komunikasi. Tidak heran jika apapun gaya yang sedang trend di Barat dengan cepat diadopsi dan bisa ditemukan serta dikonsumsi oleh masyarakat Indonesia.

Gaya hidup global yang difasilitasi oleh teknologi komunikasi yang makin canggih juga diwacanakan oleh film remaja pada dekade 2000-an. Remaja di dalam film ini, digambarkan sebagai remaja yang melek teknologi. Joshua misalnya, digambarkan belajar tentang seluk-beluk pistol dan cara merakitnya dari internet. Handphone pun digambarkan sebagai alat komunikasi yang sudah biasa dan tidak bisa dilepaskan dari kehidupan sehari-hari kaum remaja. Akibat dari perkembangan teknologi dan konsumsi teknologi yang dilakukan oleh remaja, berbagai hal yang datang dari Barat pun seolah tidak terfilter lagi. Artinya, remaja bisa dengan bebas mengaksesnya dan digambarkan mengikutinya. Seperti penyanderaan yang dilakukan oleh Joshua, oleh film Ekskul perilaku itu dianggap seperti kisah di dalam film-film Barat Hollywood. Joshua sendiri dengan teknologi internet dan media mempelajari drama penyanderaan dan juga cara menggunakan senjata. Cara mengakhiri hidupnya pun, juga mencontoh cara Kurt Cobain yang notabene adalah penyanyi dari Barat. Berbagai hal yang berbau Barat menjadi sesuatu yang sudah akrab menjadi bagian dari gaya hidup remaja dan tidak diwacanakan sebagai sesuatu yang negatif.

\section{SIMPULAN}

Analisis terhadap delapan film remaja yang diproduksi dari tahun 1970-an hingga 1980-an menunjukkan adanya pergeseran wacana tentang dinamika dunia remaja yang semakin kompleks dari dekade ke dekade. Wacana tentang remaja yang dianggap baik dan remaja yang dianggap nakal cenderung tidak berubah dari dekade ke dekade. Remaja yang baik selalu diwacanakan lewat figur remaja yang pandai, aktif, dan berprestasi. Sedangkan remaja yang nakal adalah remaja yang suka membuat masalah baik di rumah maupun di sekolah, merokok, mabuk, dan suka berkelahi. Dalam proses pembentukan identitas dirinya, remaja juga digambarkan membutuhkan role model yang dari dekade ke dekade selalu mengacu pada figur yang berasal dari Barat, khususnya dari Amerika dan Eropa. Gaya hidup yang dipengaruhi oleh budaya asing semakin dianggap sebagai sesuatu yang ideal, dianggap lebih baik, ditiru, dan menjadi indikator perkembangan zaman. 
Remaja yang tidak mengikutinya cenderung dianggap sebagai kuno dan ketinggalan zaman.

\section{DAFTAR PUSTAKA}

Brown, Jane Delano, Jeanne R. Steele and Kim Walsh, 2002, Sexual Teens, Sexual Media, Lawrence Erlbaum Associates.

Clark, M., 2004, Men, Masculinities and Symbolic Violence in Indonesian Cinema dalam Journal of Southeast Asian Studies Vol. 35 (1), hlm. 113-131.

Corey, A. and Valerie V. P., 2003, “Who Said What: Subject Positions, Rhetorical Strategies and Good Faith." In Communication Studies Journal, Winter. Diunduh dari http://findarticles. com/ p/articles/mi_qa3669/is_200301/ ai_n9235810 [Diakses pada 05 July 2007].

Fairclough, N., 2000, Critical Analysis of Media Discourse", dalam Paul Marris \& Sue Thornham (eds.), Media Studies: A Reader, 2nd ed. Washington Square, New York: New York University Press.

Grant, B. K., 2003, Film Genre Reader III, Texas: University of Texas Press.

Gross, C. M., Anne N. Rinn \& Kelly M. Jamieson, 2007, Gifted Adolescents' Overexcitabilities and Self-Concept dalam Roeper Review Vol 29 No. 4, hlm. 240248.

Hall, S., 1995, "The White of Their Eyes: Racist Ideologies and the Media", dalam Dines, Gail and Jean M. Humez (eds.), Gender, Race and Class in Media: A Text Reader, London: Thousand Oaks \& New Delhi: Sage Publications. , 1997, Representation: Cultural Representations and Signifying Practices, London, Thousand Oaks, New Delhi: Sage.

Hanan, D., 2008, “Changing Social Formations in Indonesian and Thai Teen Movies", dalam Ariel Heryanto (ed.), Popular Culture in Indonesia: Fluid Identities in Post-Authoritarian Politics. London: Routledge, hlm. 54-69.
Herald, J., 2007, Fashions of a Decade The 1970s, New York: Chelsea House.

Hurlock, E., 1999, Psikologi Perkembangan, Jakarta: Erlangga.

Icon Group International, 2008, Teenagers: Webster's Quotations, Facts and Phrases.

Kellner, D., 1995, Media Culture: Cultural Studies, Identity and Politics bet-ween the Modern and the Postmodern, London \& New York: Routledge.

Kirsh, S. J., 2006, Children, Adoloscents and Media Violence, London: Sage.

Pandergast, S., Pandergast. T., 2004, Fashion, Costume and Culture: Clothing, Headwear, Body Decorations, and Foot-wear through Ages, vol, Modern World Part II: 1946 to 2003. New York: Thomas \& Gale.

Retnaningish, R., 1996, Aktualisasi Diri, Jakarta: Gunadarma.

Shary, T., 2005, Teen Movies: American Youth on Screen, New York: Wallflower Press.

Siregar, A., 2008, Manfaat Media untuk Menunjang Perkembangan Remaja. Diunduh dari http:/ / ashadisiregar.files. wordpress.com/2008/08/manfaatmedia-massa-perkembangan-remaja. pdf (Diakses pada 10 Maret 2009).

Sen, K. and David T. Hill, 2000, Media, Culture and Politics in Indonesia, New York: Oxford University Press.

Tanjung, A., 2007, The Golkar Way: Survival Partai Golkar di Tengah Turbulensi Politik Era Transisi, Jakarta: Gramedia Pustaka Utama.

Vickers, A., 2005, A History of Modern Indonesia, Cambridge: Cambridge University Press.

Widyastuti, R., 2006, Remaja dan Media, Kompas, 10 Februari 2006.

Yudhistira, Wiratama. A., 2010, Dilarang Gondrong: Praktik Kekuasaan Orde Baru Terhadap Anak Muda Awal 1970an, Jakarta: http://www. davidcassidy. com. (Diakses tanggal 23 Agustus 2009). 